Original Article

\title{
FORMULATION AND EVALUATION OF MASLINIC ACID LOADED TRANSDERMAL PATCHES
}

\author{
NEHA CHOUDHORY*, TARANJIT KAUR, AJEET PAL SINGH, AMAR PAL SINGH
}

St. Soldier Institute of Pharmacy, Lidhran Campus, Behind NIT (R. E. C), Jalandhar-Amritsar bypass NH-1 Jalandhar 144011, Punjab, India Email: ajaykumar.rana97@gmail.com

Received: 04 Aug 2021, Revised and Accepted: 10 Oct 2021

\section{ABSTRACT}

Objective: To develop and evaluate Transdermal patch of Maslinic acid for Transdermal drug delivery. The current study is to develop Transdermal drug delivery system.

Methods: Suitable method such as Solvent Casting Technique of Film Casting Technique are used for preparation of Transdermal patch.

Results: The prepared Transdermal patches were transparent, smooth, uniform and flexible. The method adopted for the preparation of the system was found satisfactory.

Conclusion: Various formulations were developed by using hydrophilic and hydrophobic polymers like HPMC E5 and EC respectively in single and combinations by solvent evaporation technique with the incorporation of penetration enhancer such as dimethylsulfoxide and dibutyl phthalate as plasticizer In vitro studies concluded that HPMC E5 patches has better release than that of EC patches, which may be attributed to high water vapour permeability of HPMC patches and hydrophobic nature of EC. An attempt was made to incorporate HPMC E5 and EC to the monolithic system for better release and prolong the duration of release. Formulation F7 containing an equal ratio of HPMC E5: EC (5:5) showed maximum and sustained release of $86.816 \pm 0.264$ within $24 \mathrm{~h}$. Kinetic models were used to confirm the release mechanism of the formulations. Maslinic acid release from the patches F1 to F7 followed non Fickian diffusion rate controlled mechanism.

Keywords: Controlled DDS, Transdermal DDS, Maslinic acid, Transdermal patch, Solvent evaporation method

(C) 2021 The Authors. Published by Innovare Academic Sciences Pvt Ltd. This is an open access article under the CC BY license (https://creativecommons.org/licenses/by/4.0/) DOI: https://dx.doi.org/10.22159/ijcpr.2021v13i6.1933 Journal homepage: https://innovareacademics.in/journals/index.php/ijcpr

\section{INTRODUCTION}

A transdermal patch is a medicated adhesive patch that is placed on the skin to deliver a specific dose of medication through the skin and into the bloodstream. Often, this promotes healing to an injured area of the body. An advantage of a transdermal drug delivery route over other types of medication delivery such as oral, topical, intravenous, intramuscular, etc. is that the patch provides a controlled release of the medication into the patient, usually through either a porous membrane covering a reservoir of medication or through body heat melting thin layers of medication embedded in the adhesive. The main disadvantage to transdermal delivery systems stems from the fact that the skin is a very effective barrier; as a result, only medications whose molecules are small enough to penetrate the skin can be delivered in this method. A wide variety of pharmaceuticals are now available in transdermal patch form [1].

Administration of drug in conventional dosage form requires-large dose, frequent administration and lacks extended duration, with chances of toxicity. While in controlled drug delivery devices, there is efficient utilization of the drug, desired extended duration, with very low chances of toxicity, facilitating enhanced complication of the patient, leading to better management of therapeutics. The efficacious use of drugs influences cost factor and the economy of therapy too. It seems that controlled delivery should be the goal for all products and now a day's drug firms have been allocating large resources on the reformulation of older, existing drugs in sustained and controlled drug delivery often resulting in special economic gains [2].

A novel drug delivery approach known as a controlled release drug delivery system evolves, which facilitates the drug release into systemic circulation at a pre-determined rate [3]. A class of novel drug delivery systems is Transdermal drug delivery systems (TDDS) which can deliver medicines via the skin portal to systemic circulation at a predetermined rate and maintain clinically effective concentrations over a prolonged period of time $[4,5]$.

\section{Maslinic acid}

Maslinic acid, a naturally occurring dihydroxy triterpenoid having a 6-66-6-6 fused pentacyclic structure, is extractable from the fruits of olive
(Olea europaea). Maslinic acid is a compound derived from dry olivepomace oil (an olive skin wax) which is a byproduct of olive oil extraction. It is a member of the group of triterpenes known as oleananes. Maslinic acid is a pentacyclic triterpene found in a variety of natural sources, ranging from herbal remedies used in traditional Asian medicine to edible vegetables and fruits present in the Mediterranean diet. In recent years, several studies have proved that maslinic acid exerts a wide range of biological activities, i.e. antitumor, antidiabetic, antioxidant, cardioprotective, neuroprotective, antiparasitic and growthstimulating. Experimental models used for the assessment of maslinic acid effects include established cell lines, which have been often used to elucidate the underlying mechanisms of action, and also animal models of different disorders, which have confirmed the effects of the triterpene in vivo. Overall, and supported by the lack of adverse effects in mice, the results provide evidence of the potential of maslinic acid as a nutraceutical, not only for health promotion but also as a therapeutic adjuvant in the treatment of several disorders $[6,7]$.

\section{Methods \\ Pre-formulation studies}

\section{Determination of melting point}

Melting point of the drug was determined by taking a small amount of drug in a capillary tube closed at one end. The capillary tube was placed in a melting point apparatus and the temperature at which drug melts was recorded. This was performed thrice and an average value was noted [8].

\section{Determination of solubility}

An excess amount of the drug was taken and dissolved in a measured volume of distilled water in a volumetric flask to get a saturated solution. The solution was kept for $24 \mathrm{~h}$ at room temperature for the attainment of equilibrium. These solutions were kept for sonication and then supernatant were filtered using a 0.45micron whatmann filter paper to separate the undissolved drug particles and diluted suitably and the concentration of Maslinic acid 
in the filtrate was determined spectrophotometrically by measuring at $300 \mathrm{~nm}$.

\section{Determination of partition coefficient}

The partition coefficient of the drug was determined by taking equal volumes of 1-octanol and aqueous solution in a separating funnel. In case of water-soluble drugs, a drug solution was prepared in distilled water, and in the case of water-insoluble drugs, a drug solution of was prepared in 1-octanol. Standard solution of the drug was prepared in this phosphate buffer $\mathrm{pH} 7.4$ solution.

Octanol (10 ml) was added to an equal volume of this standard drug solution in a separating funnel and was kept for $24 \mathrm{~h}$ at $37 \pm{ }^{\circ} \mathrm{C}$ with intermittent shaking. Finally, the buffer solution was separated, clarified by centrifugation and assayed for drug content.

\section{Determination of drug-excipients compatibility}

\section{FT-IR}

In the preparation of film formulation, drug and polymer may interact as they are in close contact with each other, which could lead to the instability of drug, Preformulation studies regarding the drug-polymer interaction are therefore very critical in selecting appropriate polymers. FT-IR spectroscopy was employed to ascertain the compatibility between Maslinic acid and the selected polymers. The pure drug and drug with excipients were scanned separately.

\section{Procedure}

Potassium bromide was mixed with drug and/or polymer and the spectra were taken. FT-IR spectrum of Maslinic acid was compared with FT-IR spectra of Maslinic acid with polymer. Disappearance of Maslinic acid peaks or shifting of the peak in any of the spectra was studied [10].

\section{Procurement of standard drug}

Maslinic acid was procured from Sigma Aldrich (Merck).

\section{Characterization of maslinic acid}

\section{DSC of maslinic acid}

Purity profile of the drug was determined by using differential scanning calorimetry (DSC). The latter can be assessed by the melting behavior observed in the recorded thermogram. The main application of DSC to purity relies on the notion that impurities reduce the melting temperature of the drug. The melting temperature is a strong indication of drug purity. For carrying out DSC of the model drug, $0.5 \mathrm{mg}$ of sample was placed in aluminum pan. The pan was crimped using a punching press. The sample pan was placed in pan holder of the DSC machine. The sample was run at a ramp rate of $10^{\circ} \mathrm{C} / \mathrm{min}$ from $25^{\circ} \mathrm{C}$ to $300^{\circ} \mathrm{C}$ with a flow rate of $60 \mathrm{ml} / \mathrm{min}$ for nitrogen [11].

\section{Calibration curve of maslinic acid}

The standard calibration curve was constructed to obtain a regression line equation to be used for finding out the concentration of drug in samples. Two calibration curves of the drug were plotted; one by RP-HPLC method and one by UV spectrophotometer. ${ }^{2}$ Calibration curve by RP-HPLC method was used for assay of drug in gel matrix for entrapment efficiency studies. The other one was plotted by UV spectrophotometer using Ethanolic phosphate buffer (pH 7.4) for carrying out in vitro drug release studies [12].

\section{Standard solution of drug}

To make a stock solution, $10 \mathrm{mg}$ of Maslinic acid was weighed and transferred to $100 \mathrm{ml}$ volumetric flask. Volume was made up to the mark with mobile phase to obtain a solution of $100 \mu \mathrm{g} / \mathrm{ml}$. It was further diluted to obtain a secondary stock solution of $10 \mu \mathrm{g} / \mathrm{ml}$. Appropriate aliquots of secondary stock solution of $10 \mu \mathrm{g} / \mathrm{ml}$ were taken in $10 \mathrm{ml}$ volumetric flasks and diluted up to the mark with mobile phase to obtain final concentrations of $0.5,2.0,3.0,4.0$ and $10.0 \mu \mathrm{g} / \mathrm{ml}$ of the model drug.

\section{Preparation of standard solution}

To make a stock solution, accurately weighed $1.0 \mathrm{mg}$ of Maslinic acid was dissolved in Ethanolic phosphate buffer (7.4) in $10 \mathrm{ml}$ volumetric flask and volume were made up to the mark with Ethanolic phosphate buffer (7.4) to give a clear solution of 1000 $\mu \mathrm{g} / \mathrm{ml}$ concentration. It was further diluted to obtain a secondary stock solution of $100 \mu \mathrm{g} / \mathrm{ml}$. A series of different concentrations of drug were prepared from secondary stock solution i.e. 0.5, 1.0, 1.5, $2.0,2.5$ and $5.0 \mathrm{ml}$ solutions were pipette out from secondary stock solution and were transferred in to $10 \mathrm{ml}$ volumetric flasks to obtain a solution of $5,10,15,20,25,50 \mu \mathrm{g} / \mathrm{ml}$ respectively on making up the solution to $10 \mathrm{ml}$ with Ethanolic phosphate buffer (7.4).

\section{Preparation of drug-phosphatidylcholine complex (D-PC)}

The complex was prepared with drug and phospholipids in a suitable molar ratio. The required amount of drug and phospholipids were put in a $250 \mathrm{ml}$ round bottom flask and $20 \mathrm{ml}$ reaction solvent was added. The mixture was refluxed at a suitable temperature for the required time period. To the concentrate, n-hexane was added to precipitate D-PC and filtered and dried to remove traces of solvents. The dried D-PC obtained was weighed using electronic balance and stored at room temperature for further use [13].

\section{Preparation of transdermal patches}

Transdermal patches containing Maslinic acid were prepared by the solvent evaporation technique in cylindrical glass molds with both sides opens. The backing membrane was cast by pouring a 2 $\%(\mathrm{~m} / \mathrm{V})$ polyvinyl alcohol (PVA) solution followed by drying at $60{ }^{\circ} \mathrm{C}$ for $6 \mathrm{~h}$. The drug reservoir was prepared by dissolving D-PC in Chloroform: Methanol (1:1) mixture. Dibutylphthalate $15 \%(w / w$ of dry polymer composition) was used as a plasticizer. The drug $0.5 \mathrm{mg}$ (in $5 \mathrm{ml}$ solvent mixture Chloroform: Methanol) was added into the homogeneous dispersion under slow stirring with a magnetic stirrer. The uniform dispersion was cast on a PVA backing membrane and dried at room temperature. The films were stored between sheets of wax paper in desiccators [13].

\section{Evaluation of transdermal patches [14-17]}

\section{A. Physical appearance}

All the prepared patches were visually inspected for color, clarity, flexibility and smoothness.

\section{B. Thickness uniformity}

The aim of the present study was to check the uniformity of thickness of the formulated films. The thickness of the film was measured at 3 different points using a digital caliper and an average thickness of three reading was calculated.

\section{Weight uniformity}

For each formulation, three randomly selected patches were used. For the weight variation test, 3 films from each batch were weighed individually and the average weight was calculated.

\section{Folding endurance}

The folding endurance was measured manually for the prepared films. A strip of film $(5 \times 5 \mathrm{~cm})$ was cut and repeatedly folded at the same place till it broke. The number of times the film could be folded at the same place without breaking/cracking gave the value of folding endurance.

\section{E. Percentage moisture absorption}

The films were weighed accurately and placed in the desiccators containing $100 \mathrm{ml}$ of a saturated solution of potassium chloride, which maintains $80-90 \%$ RH. After $3 \mathrm{~d}$, the films were taken out and weighed. The study was performed at room temperature. The percentage moisture absorption was calculated using the formula:

\section{Percentage moisture absorption $=$ Final Weight-Initial} Weight/Initial Weight X 100

\section{F. Percentage moisture loss}

The films were weighed accurately and kept in a desiccators containing anhydrous calcium chloride. After $3 \mathrm{~d}$, the films were taken out and weighed. The moisture loss was calculated using the formula: 
Percentage moisture loss $=$ Final Weight-Initial Weight/Initial Weight X 100

\section{G. Water vapors transmission rate}

Glass vials of $5 \mathrm{ml}$ capacity were washed thoroughly and dried to a constant weight in an oven. About $1 \mathrm{gm}$ of fused calcium chloride was taken in the vials and the polymer films of $1.44 \mathrm{~cm} 2$ were fixed over the brim with the help of an adhesive tape. Then the vials were weighed and stored in a humidity chamber of $80-90 \% \mathrm{RH}$ condition for a period of 24 $\mathrm{h}$. The vials were removed and weighed at the time interval of $24 \mathrm{~h}$ for three consecutive days to note down the weight gain.

Water vapor transmission rate $=$ Final Weight-Initial Weight $/$ Time $\mathrm{X}$ Area X 100

\section{H. Tensile strength}

Tensile strength of the film was determined with a Universal strength testing machine (Hounsfield, Slinfold, Horsham, U. K.). The sensitivity of the machine was 1 gram. It consisted of two load cell grips. The lower one was fixed and the upper one was movable. The test film of size $\left(4 \times 1 \mathrm{~cm}^{2}\right)$ was fixed between these cell grips and force was gradually applied till the film broke. The tensile strength of the film was taken directly from the dial reading in $\mathrm{kg}$. Tensile strength is expressed as follows;

Tensile strength $=$ Tensile load at Break/Cross-Sectional Area

\section{Drug content uniformity of films}

The patches $\left(1 \mathrm{~cm}^{2}\right)$ were cut and added to a beaker containing 100 $\mathrm{ml}$ of phosphate-buffered saline of $\mathrm{pH}$ 7.4. The medium was stirred with magnetic bead. The contents were filtered using whatmann filter paper and the filtrate was examined for the drug content against the reference solution consisting of placebo films (containing no drug) at $215 \mathrm{~nm}$ spectrophotometrically. The experiment was repeated to validate the result.

\section{J. In vitro drug release studies}

In vitro skin permeation studies were performed by using a modified Franz diffusion cell with a receptor compartment capacity of $20 \mathrm{ml}$. The synthetic cellophane membrane was mounted between the donor and receptor compartment of the diffusion cell. The formulated patches were cut into the size of $1 \mathrm{~cm}^{2}$ and placed over the drug release membrane and the receptor compartment of the diffusion cell was filled with phosphate buffer $\mathrm{pH}$ 7.4. The whole assembly was fixed on a magnetic stirrer, and the solution in the receptor compartment was constantly and continuously stirred using magnetic beads at $50 \mathrm{rpm}$; the temperature was maintained at $37 \pm 0.5^{\circ} \mathrm{C}$. The samples of $1 \mathrm{ml}$ were withdrawn at the time interval of $1,2,3,4,5,6,7,8,9,10,11,12$, and $24 \mathrm{~h}$, analyzed for drug content spectrophotometrically at $215 \mathrm{~nm}$ against blank. The receptor phase was replenished with an equal volume of phosphate buffer at each time of sample withdrawal. The cumulative amounts of drug permeated per square centimeter of patches were plotted against time.

The diffusion kinetics of the drug Maslinic acid were analyzed by graphical method.

$>$ Zero-order graphs were made by plotting Cumulative \% drug release against Time in hours.

$>$ First-order graphs were made by using Log cumulative \% drug remaining against Time in hours.

$>$ The diffusion pattern release of the formulation was studied by plotting Higuchi's graph using Cumulative \% drug released against Square root of time.

$>$ The Peppas exponential equation was explained by plotting a graph of Log of cumulative \% drug release against Log time.

\section{RESULTS AND DISCUSSION}

Pre-formulation studies

Drug: Maslinic acid

Physical description: Solid

Color/form: Crystalline solid

Melting point: $249-250^{\circ} \mathrm{C}$

Solubility: Solubility of $0.3 \mathrm{mg} / \mathrm{ml}$ in a $1: 2$ solution of Ethanol: Buffered Water ( $\mathrm{pH} \mathrm{7.2)}$ ) at $25^{\circ} \mathrm{C}$. In ethanol: $0.5 \mathrm{mg} / \mathrm{ml}$; in DMSO: 20 $\mathrm{mg} / \mathrm{ml}$; in dimethyl formamide: $15 \mathrm{mg} / \mathrm{ml}$. sparingly soluble in aqueous buffers.

Density: $1.15 \mathrm{~g} / \mathrm{cu} \mathrm{cm}$

Vapor pressure: $2.3 \mathrm{X} 10-15 \mathrm{~mm} \mathrm{Hg}$ at $25^{\circ} \mathrm{C}$

\section{Drug excipients compatibility studies}

FT-IR spectrum and values

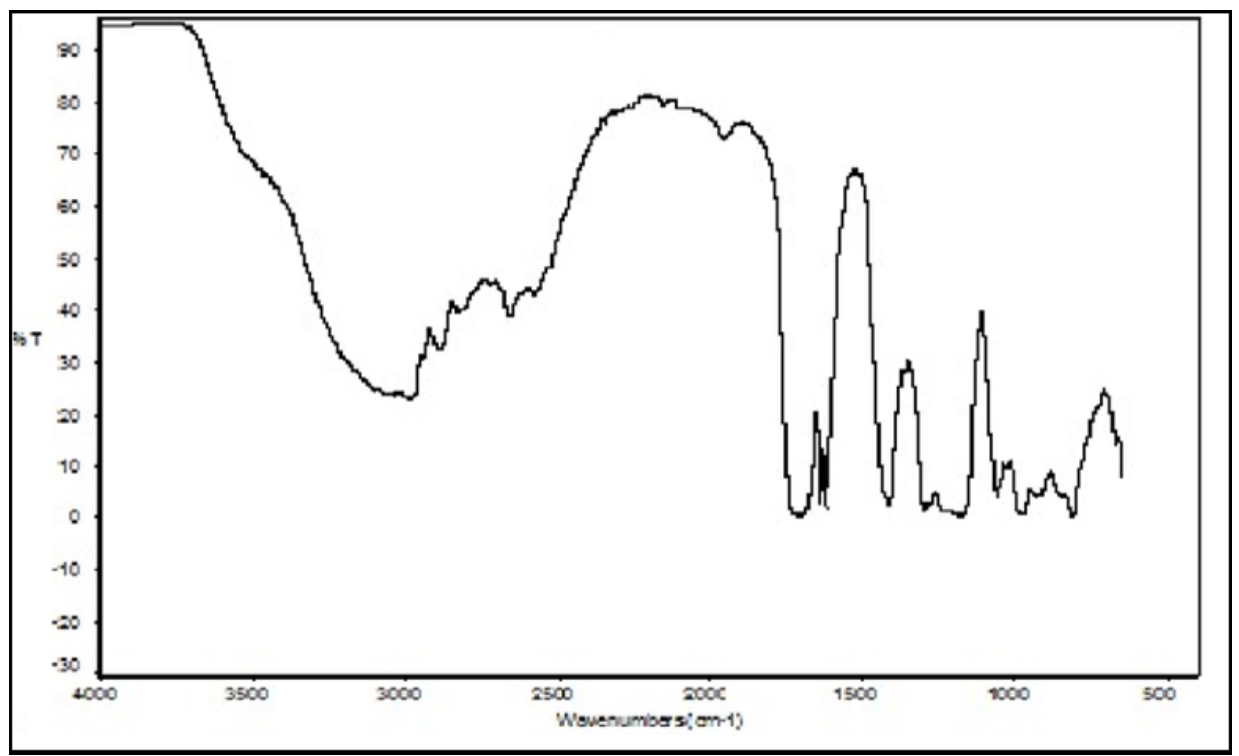

Fig. 1: Spectrum of pure maslinic acid 


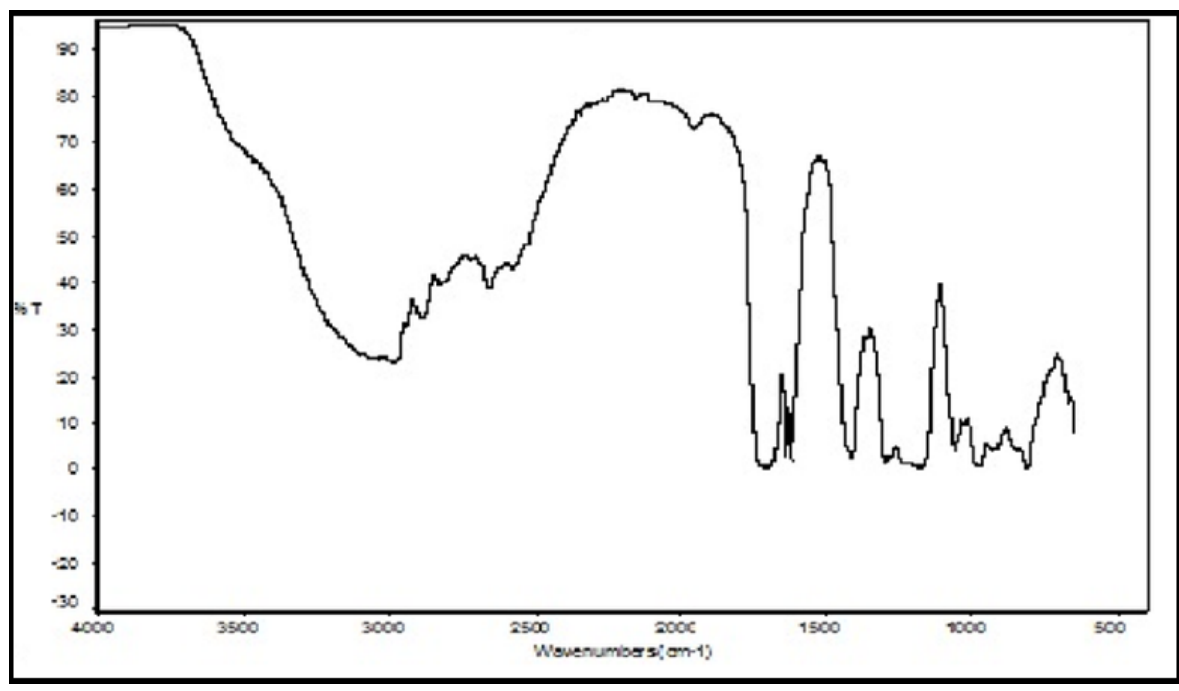

Fig. 2: IR Spectrum of pure HPMC E5

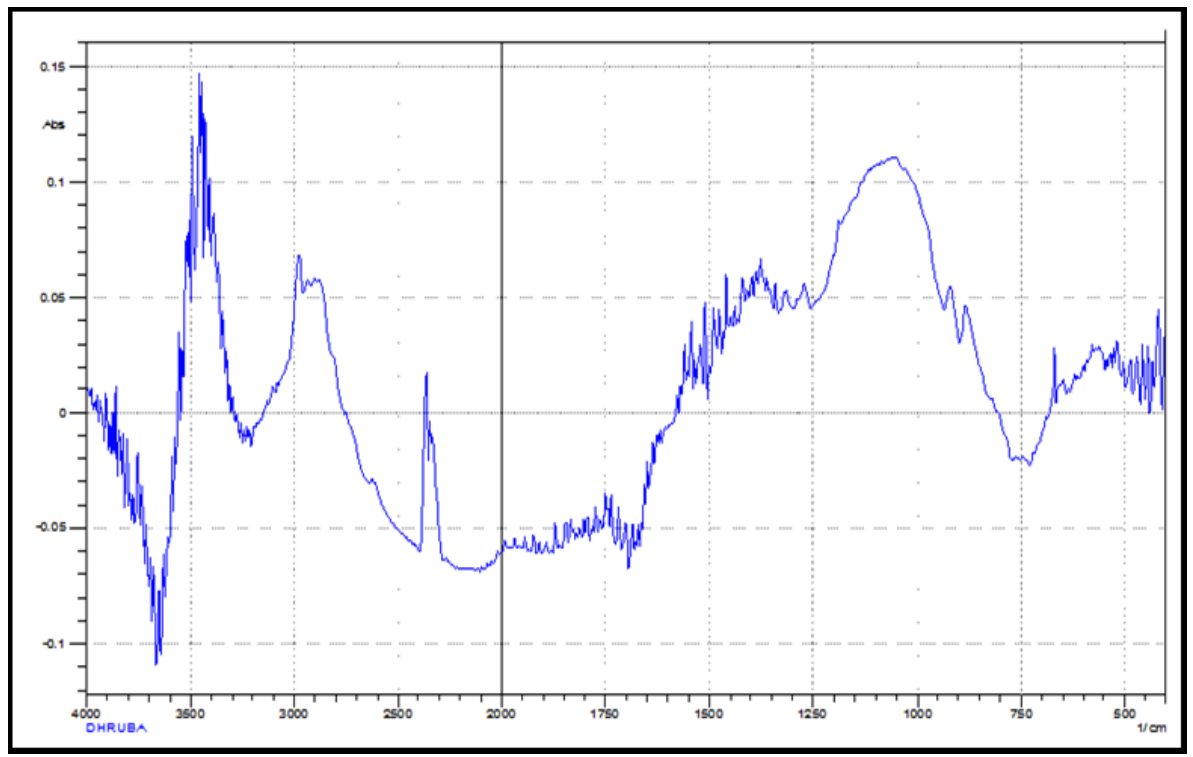

Fig. 3: IR spectrum of pure EC

Table 1: FT-IR spectrum values

\begin{tabular}{|c|c|c|c|c|}
\hline S. No. & IR spectrum of & Groups & $\operatorname{Peak}\left(\mathrm{cm}^{-1}\right)$ & Stretching/Deformation \\
\hline \multirow[t]{7}{*}{1} & Maslinic acid & $\mathrm{N}$-tertiary & 3436 & Stretching \\
\hline & & $\mathrm{CH} 2$ & 2692 & Stretching \\
\hline & & $\mathrm{CH} 3$ & 2345 & Stretching \\
\hline & & $\mathrm{C}=\mathrm{O}$ & 1651 & Stretching \\
\hline & & $\mathrm{C}=\mathrm{C}$ & 1477 & Stretching \\
\hline & & $\mathrm{C}-\mathrm{N}$ & 1396 & Stretching \\
\hline & & $\mathrm{C}-\mathrm{S}$ & 756 & Stretching \\
\hline \multirow[t]{2}{*}{2} & HPMC E5 & $\mathrm{O}-\mathrm{H}$ & 3463 & Stretching \\
\hline & & $\mathrm{C}-\mathrm{O}-\mathrm{C}$ & 1064 & Stretching \\
\hline \multirow[t]{3}{*}{3} & $\mathrm{EC}$ & $\mathrm{CH} 2$ & 2976 & Stretching \\
\hline & & $\mathrm{CH} 3$ & 2873 & Stretching \\
\hline & & $\mathrm{C}-\mathrm{O}-\mathrm{C}$ & 1056 & Stretching \\
\hline \multirow[t]{6}{*}{4} & Physical mixture of drug & $\mathrm{N}$-tertiary & 3436 & Stretching \\
\hline & and polymer & $\mathrm{CH} 3$ & 2927 & Stretching \\
\hline & & $\mathrm{C}=\mathrm{O}$ & 1651 & Stretching \\
\hline & & $\mathrm{C}=\mathrm{C}$ & 1473 & Stretching \\
\hline & & $\mathrm{O}-\mathrm{H}$ & 3463 & Stretching \\
\hline & & $\mathrm{C}-\mathrm{O}-\mathrm{C}$ & 1083 & Stretching \\
\hline
\end{tabular}




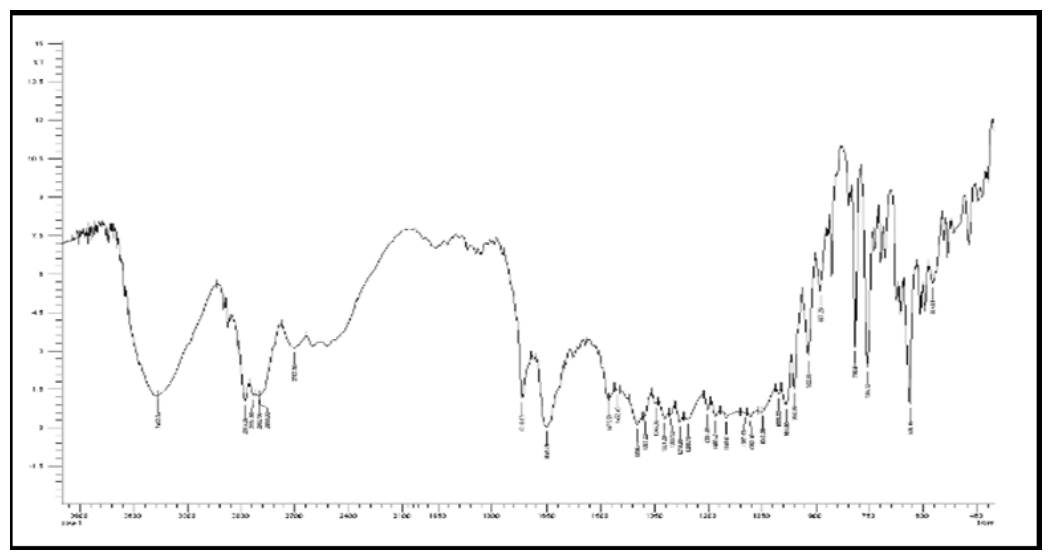

Fig. 4: IR spectrum of maslinic acid+HPMC E5+EC mixture

\section{DSC curve of maslinic acid}

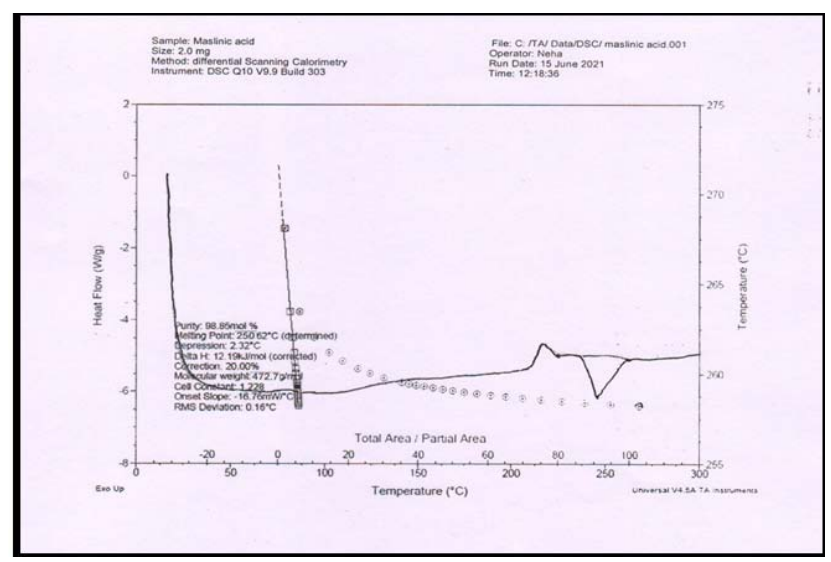

Fig. 5: DSC curve of maslinic acid

Formulation of transdermal patches

Table 2: Compositions of different formulations containing maslinic acid

\begin{tabular}{|c|c|c|c|c|c|c|c|}
\hline Formulations & F1 & F2 & F3 & F4 & F5 & F6 & F7 \\
\hline Maslinic acid, mg & 0.5 & 0.5 & 0.5 & 0.5 & 0.5 & 0.5 & 0.5 \\
\hline Ethylcellulose, mg & 300 & $*$ & 30 & 60 & 90 & 120 & 150 \\
\hline HPMC E5, mg & $*$ & 300 & 270 & 240 & 210 & 180 & 150 \\
\hline Dibutylphthalate (2drop), ml & 0.12 & 0.12 & 0.12 & 0.12 & 0.12 & 0.12 & 0.12 \\
\hline DMSO, ml & 0.06 & 0.06 & 0.06 & 0.06 & 0.06 & 0.06 & 0.06 \\
\hline Chloroform: Ethanol (1:1), ml & 5 & 5 & 5 & 5 & 5 & 5 & 5 \\
\hline
\end{tabular}

*No ingredient used, HPMC=Hydroxypropyl Methylcellulose, DMSO=Dimethyl sulphoxide

\section{Evaluation of transdermal patches}

1) Thickness uniformity

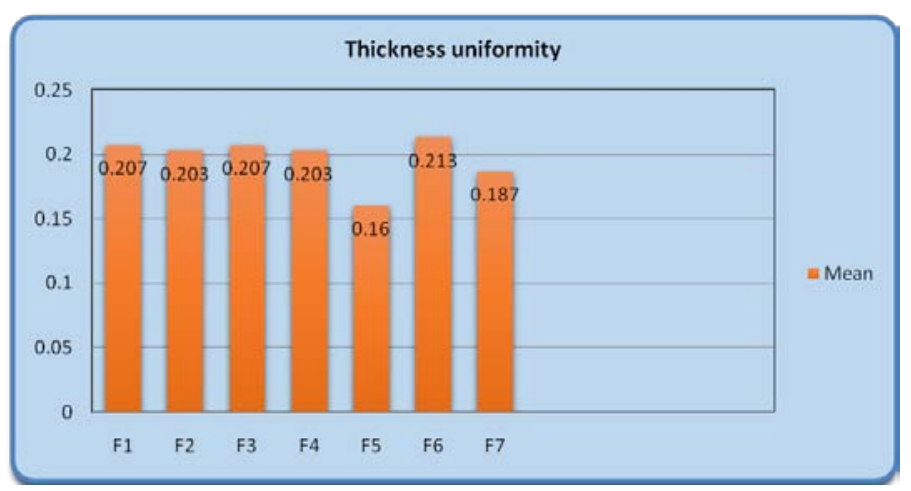

Fig. 6: Thickness uniformity 
Weight uniformity

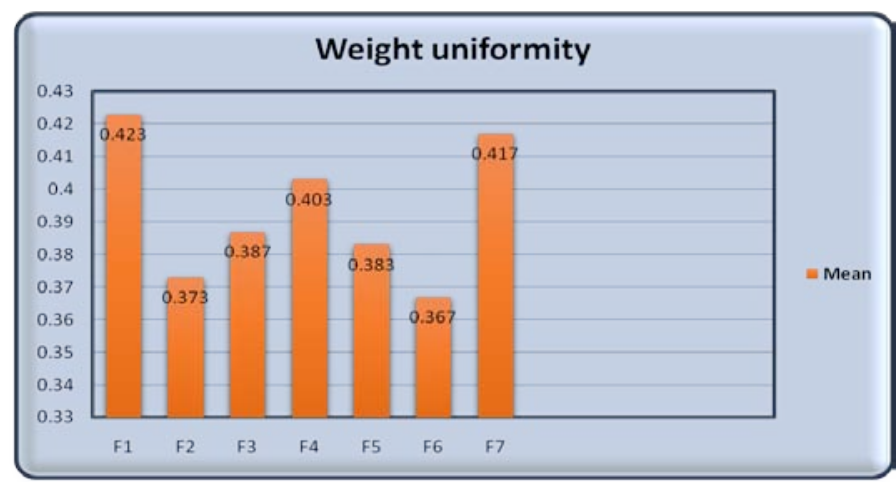

Fig. 7: Weight uniformity

Folding endurance

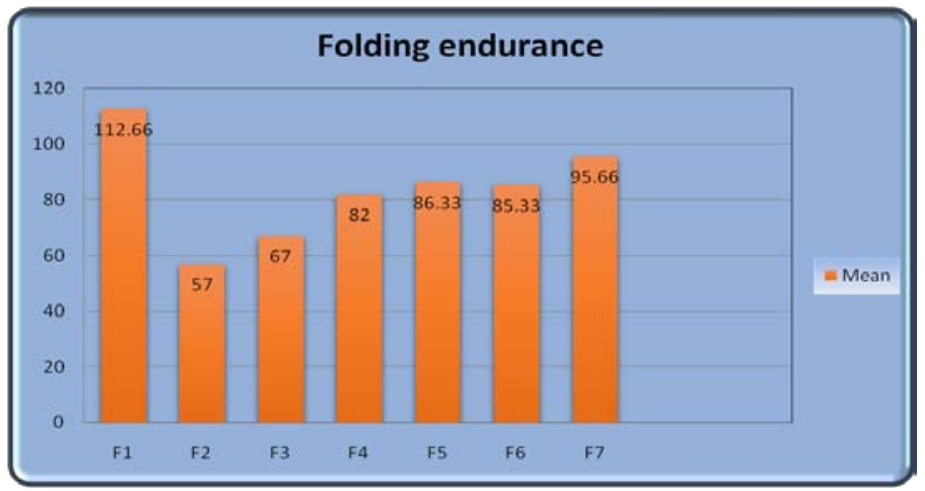

Fig. 8: Folding endurance

Percentage moisture absorption

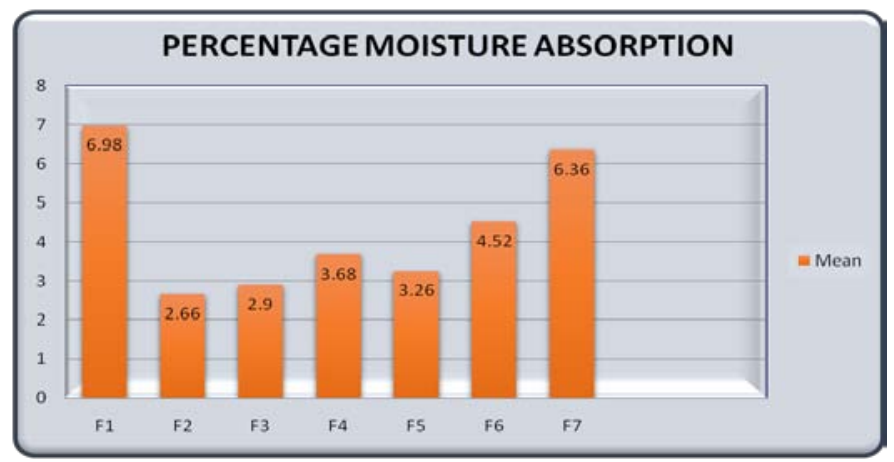

Fig. 9: Percentage moisture absorption

Percentage moisture loss

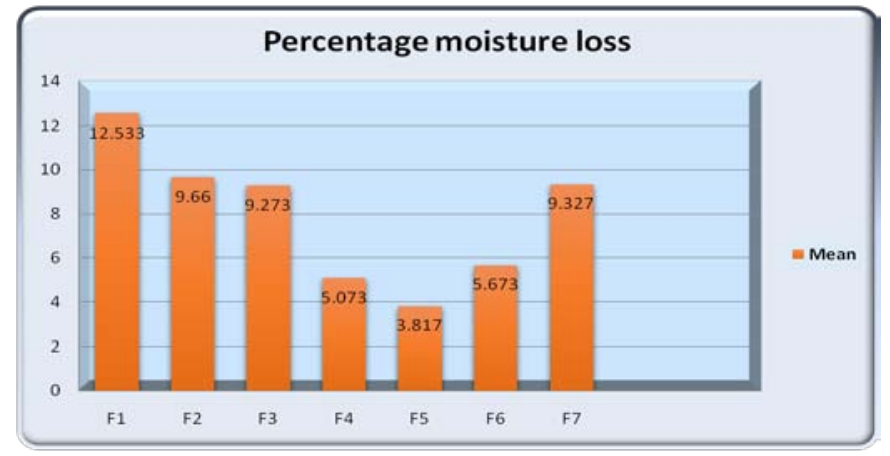

Fig. 10: Percentage moisture loss 


\section{Water vapour transition rate}

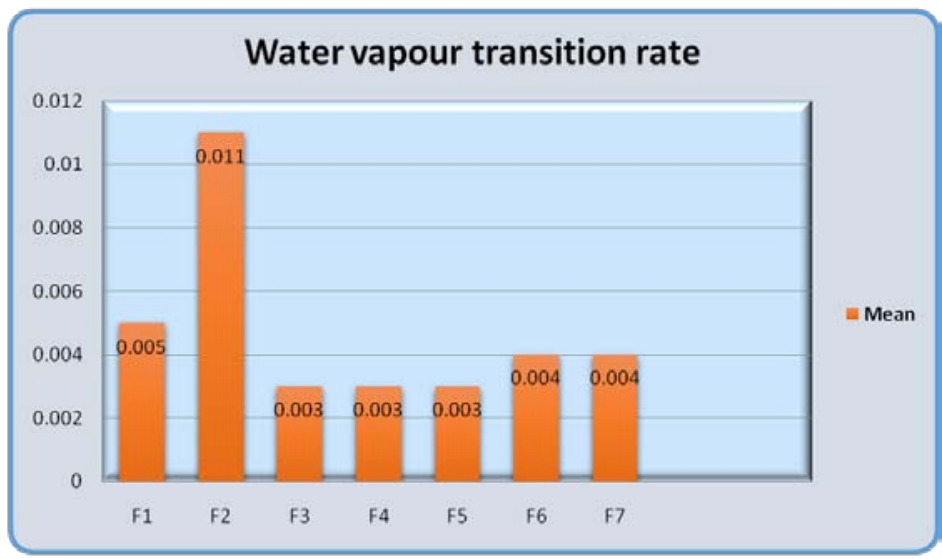

Fig. 11: percentage water vapors transition rate

\section{Tensile strength}

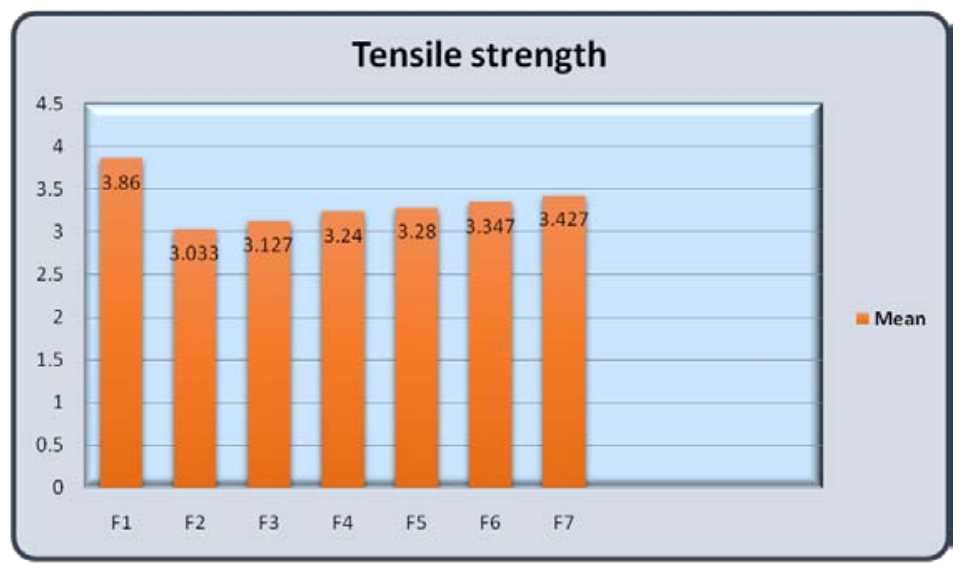

Fig. 12: Tensile strength

\section{Drug content}

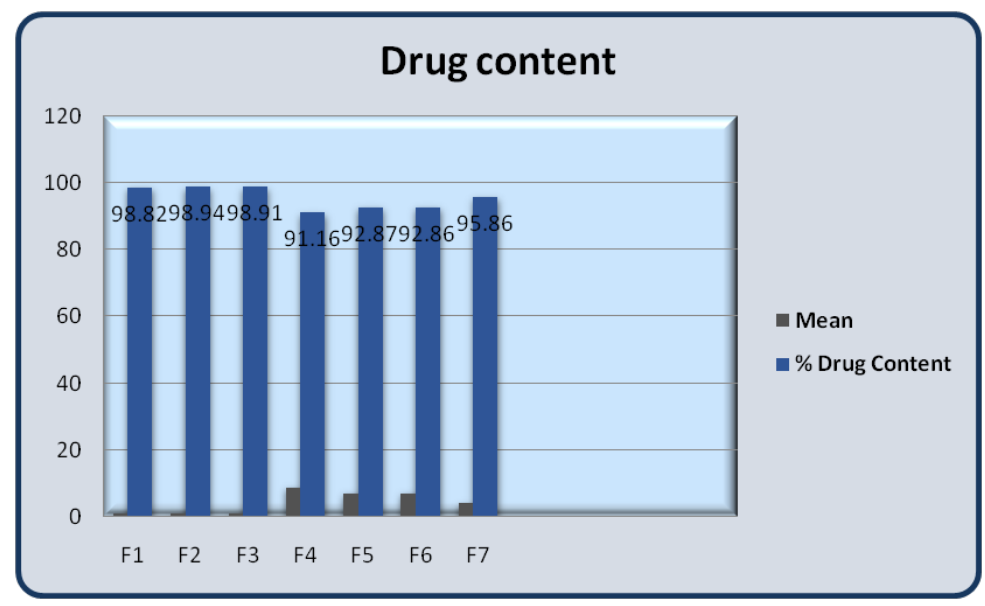

Fig. 13: Drug content

\section{Characterization of standard drug}

A single endothermic peak in case of Maslinic acid at $249.62{ }^{\circ} \mathrm{C}$ almost corresponds to its melting point as shown in fig. and table represents the different concentrations and their area under the curve for Maslinic acid by RP-HPLC method. This gives a standard curve with a linear regression equation and correlation coefficient as shown in fig. and table represents the different concentrations and their absorbance for Maslinic acid spectrophotometrically. This gives a standard curve with a linear regression equation and correlation coefficient, as shown in the figure. 
In vitro drug diffusion study

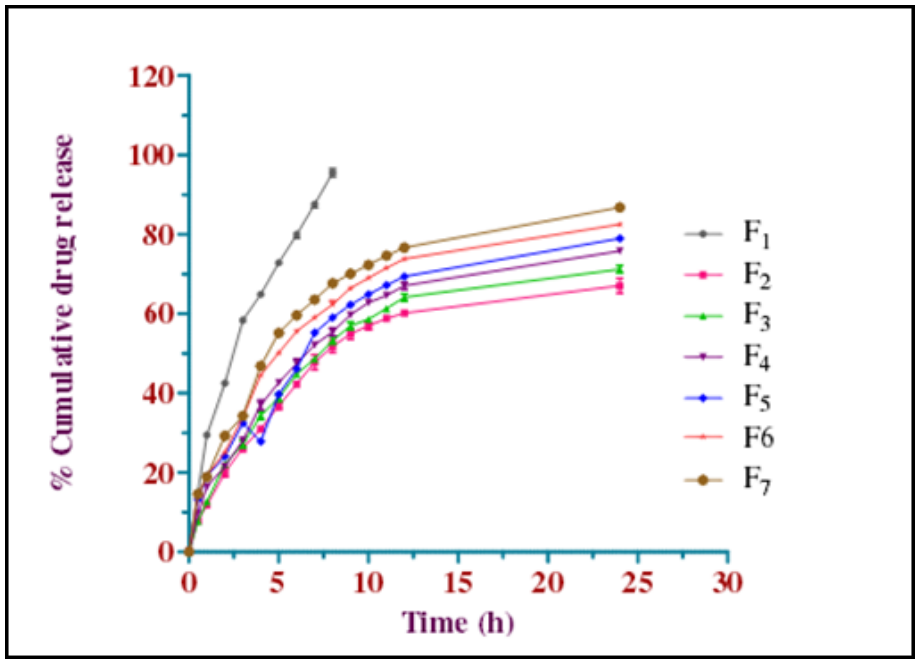

Fig. 14: Comparative in vitro release profile of maslinic acid TDDS

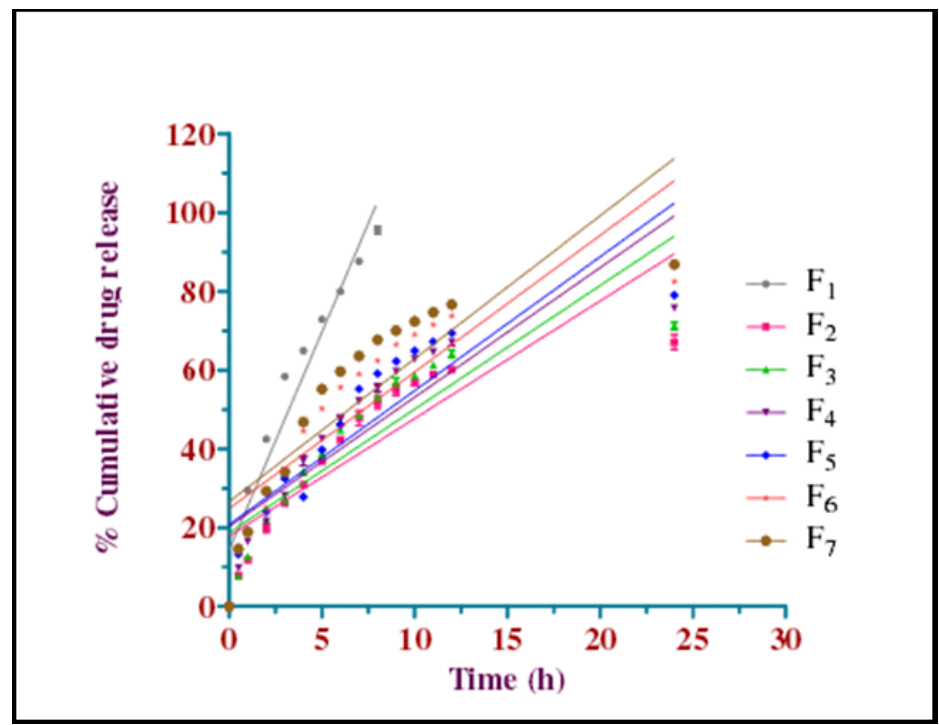

Fig. 15: Comparative in vitro release profile of maslinic acid TDDS according to zero-order kinetics

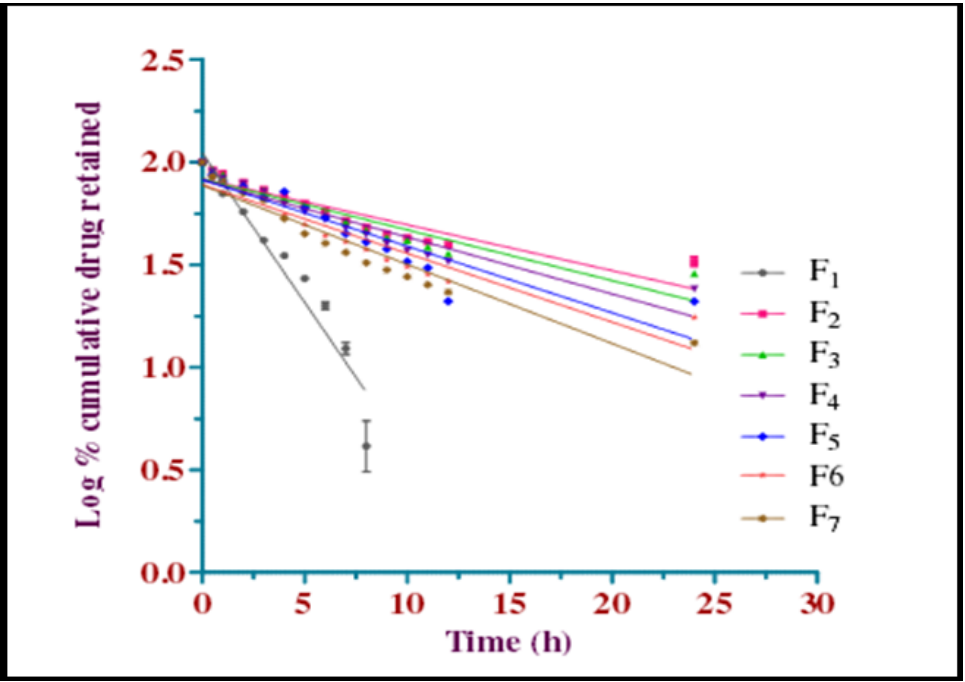

Fig. 16: Comparative in vitro release profile of Maslinic acid TDDS according to first-order kinetics 


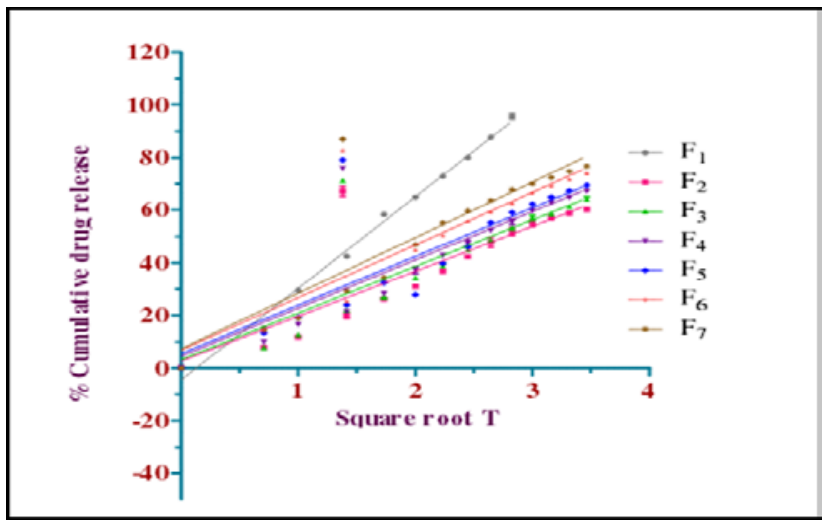

Fig. 16: Comparative in vitro release profile of maslinic acid TDDS according to higuchi plot

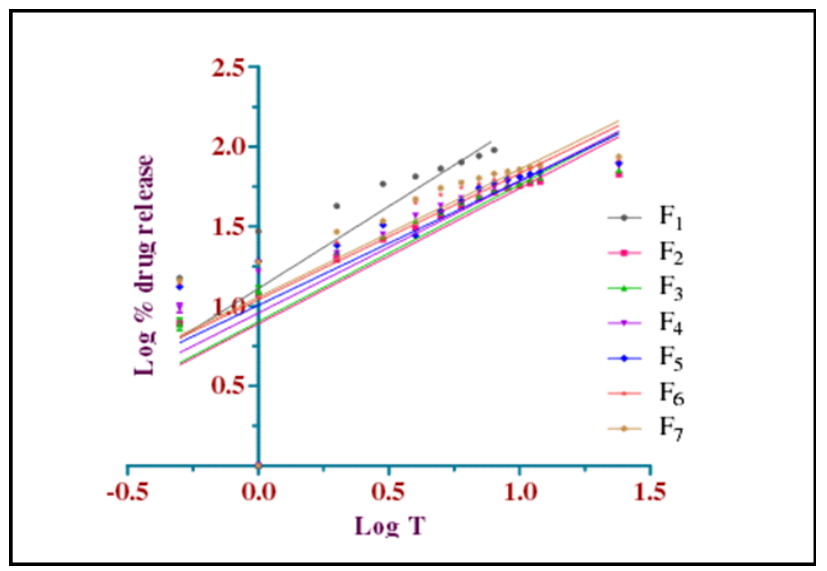

Fig. 17: Comparative in vitro release profile of maslinic acid TDDS according to peppas plot

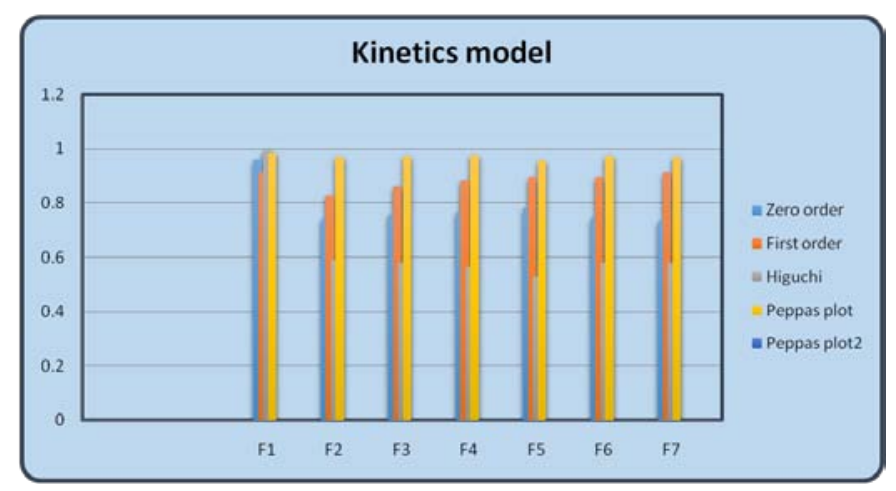

Fig. 18: Graph showing Regression coefficient $\left(R^{2}\right)$ values of different kinetics models and diffusion exponent (n) of peppas model for maslinic acid TDDS

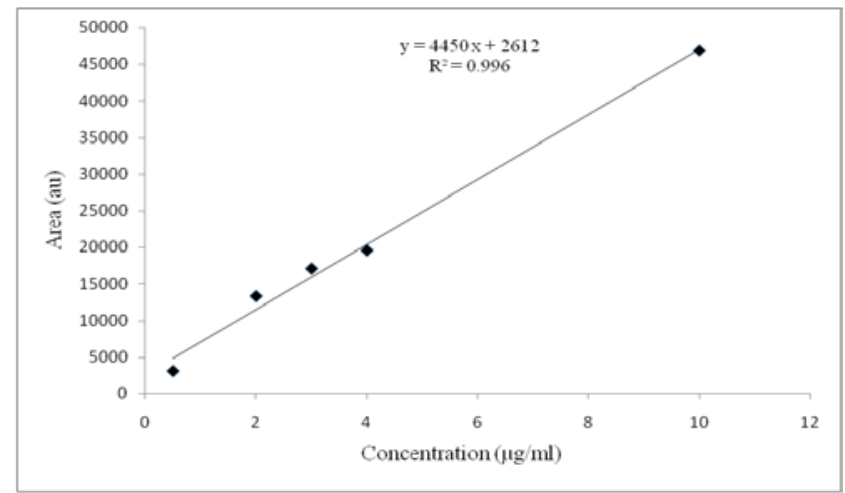

Fig. 19: Calibration curve of maslinic acid by HPLC 


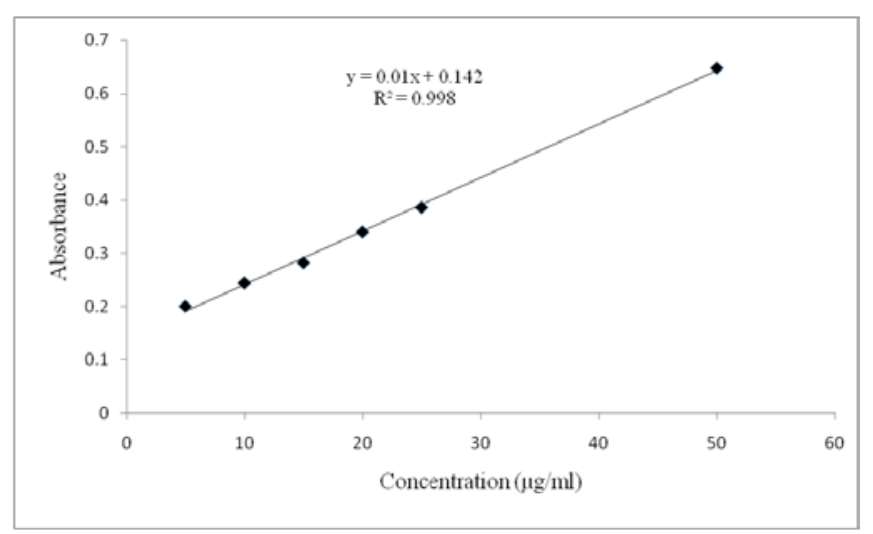

Fig. 20: Calibration curve of maslinic acid by UV spectroscopy

\section{CONCLUSION}

Various formulations utilizing hydrophilic and hydrophobic polymers like HPMC E5 and EC were created using solvent evaporation and penetration enhancers. The tensile strength of patches improved with HPMC content. Most batches had high folding endurance ratings (above 50), indicating that the patches will be less brittle when applied to the skin and retain their integrity when folded. A little quantity of wetness keeps the patch stable and avoids dry and brittle areas. In vitro experiments showed that HPMC E5 patches released more than EC patches, perhaps due to HPMC patches' high water vapour permeability and EC's hydrophobic nature. Maslinic acid transdermal patch produced via solvent evaporation. Preliminary in vivo studies on healthy animals can assess the pharmacokinetic characteristics. batch-to-batch consistency may be achieved via in vitro/in vivo correlation.

\section{ACKNOWLEDGMENT}

It's our privilege to express the profound sense of gratitude and cordial thanks to our respected chairman Mr. Anil Chopra, Vice Chairperson, Ms. Sangeeta Chopra and Pro-Chairman Mr. Prince Chopra, St. Soldier Educational Society, Jalandhar for providing the necessary facilities to complete this research work.

\section{CONFLICTS OF INTERESTS}

There are no conflicts of interest.

\section{FUNDING}

Nil

\section{AUTHORS CONTRIBUTIONS}

All the authors have contributed equally.

\section{CONFLICT OF INTERESTS}

\section{Declares none}

\section{REFERENCES}

1. Tyle P. Drug delivery device fundamental and biomedical application. New York: Marcel Dekker; 1988. p. 386-419.

2. Remington's pharmaceutical science. 17th ed. Mack Publishing Co.; 1995. p. 1644-61.

3. Panchagnula R. Transdermal delivery of drugs. Ind J Pharmacol. 1997;29:140-56.

4. Vyas SP, Roop KK. Controlled drug delivery concepts and advances. 1st ed. New Delhi: Vallabh prakash publishers; 2005. p. 411-47.

5. Sanap GS, Dama GY, Hande AS, Karpe SP, Nalawade SV, Kakade RS, Jadhav U. Preparation of transdermal monolithic systems of indapamide by solvent casting method and the use of vegetable oils as permeation enhancer. Int J Green Pharm. 2008;2(2):129-33. doi: 10.4103/0973-8258.41189.
6. Juan ME, Planas JM, Ruiz-Gutierrez V, Daniel H, Wenzel U. Antiproliferative and apoptosis-inducing effects of maslinic and oleanolic acids, two pentacyclic triterpenes from olives, on HT29 colon cancer cells. Br J Nutr. 2008;100(1):36-43. doi: 10.1017/S0007114508882979, PMID 18298868.

7. Guan T, Qian Y, Tang X, Huang M, Huang L, Li Y, Sun H. Maslinic acid, a natural inhibitor of glycogen phosphorylase, reduces cerebral ischemic injury in hyperglycemic rats by GLT-1 upregulation. J Neurosci Res. 2011;89(11):1829-39. doi: 10.1002/jnr.22671, PMID 21800347.

8. Chiu MH, Prenner EJ. Differential scanning calorimetry: an invaluable tool for a detailed thermodynamic characterization of macromolecules and their interactions. J Pharm Bioallied Sci. 2011;3(1):39-59. doi: 10.4103/0975-7406.76463, PMID 21430954.

9. Gbaguidi F, Accrombessi G, Moudachirou M, Quetin-Leclercq JQ. HPLC quantification of two isomeric triterpenic acids isolated from Mitracarpus scaber and antimicrobial activity on Dermatophilus congolensis. J Pharm Biomed Anal. 2005;39(5):990-5. doi: 10.1016/j.jpba.2005.05.030, PMID 16043321.

10. Khouloud AA, Wasfi MO, Najin MN. Adsorption of allopurinol and ketotifen by chitosan. AAPS PharmSciTech. 2001;2(1):27-33.

11. Krishnaiah YS, Satyanarayana V, Bhaskar P. Influence of limonene on the bioavailability of nicardipine hydrochloride from membrane-moderated transdermal therapeutic systems in human volunteers. Int J Pharm. 2002;247(1-2):91-102. doi: 10.1016/s0378-5173(02)00401-5, PMID 12429488.

12. Mukherjee B, Das S, Patra B, Layek B. Nefopam containing transdermal-matrix patches based on pressure-sensitive adhesive polymers. Pharm Technol; 2006. Available from: http://www.pharmtech.com. [Last accessed on 10 Jul 2021]

13. Sathyapriya LS, Jayaprakash S, Prabhu RS, Abirami A, Subramanian K, Nagarajan M. An approach to the formulation and evaluation of transdermal DDS of isoxsuprine $\mathrm{HCl}$. Int J PharmSciTech. 2008;1(1):22-8.

14. Gupta JRD, Irchhiaya R, Garud N, Tripathi P, Dubey P, Patel JR. Formulation and Evaluation of matrix type transdermal patches of glibenclamide. IJPSDR 2009;1(1). doi: 10.25004/IJPSDR.2009.010111.

15. Dandagi PM, Manavi FV, Gadag AP, Mastiholimath VS, Jagdeesh $\mathrm{T}$. Formulation of ransdermal drug delivery of ketotifen fumarate. Ind J Pharm Sci. 2003;65(3):239-43.

16. Shivhare UD, Dorlikar VP, Bhusari KP, Mathur VB, Mirani BN. Effect of polymeric compositions on pharmacotechnical properties of carvedilol transdermal film. Int J PharmSci Nanotechnol. 2009 June;1(2):457-64.

17. Murthy TEGK, Kishore VS. Effect of casting solvent and polymer on the permeability of propranolol hydrochloride through membrane controlled transdermal drug delivery system. Indian J Pharm Sci. 2007 September;69(5):646-50. doi: 10.4103/0250-474X.38469. 